\title{
Effect of tanniferous leaf meal based multi-nutrient blocks on feed intake, hematological profile, immune response, and body weight changes in Haemonchus contortus infected goats
}

\author{
Surender Singh, A. K. Pathak, R. K. Sharma and Muzaffer Khan \\ Division of Animal Nutrition, Faculty of Veterinary Sciences \& AH, Sher-e-Kashmir University of Agricultural Science and \\ Technology of Jammu, R. S. Pura-181 102, Jammu and Kashmir, India. \\ Corresponding author: A. K. Pathak, e-mail: dranandpathak1974@gmail.com, SS: surendersingh185@gmail.com, \\ RKS: drksann@rediffmail.com, MK: mmuzaffer41@gmail.com \\ Received: 15-12-2014, Revised: 04-04-2015, Accepted: 09-04-2015, Published online: 06-05-2015
}

doi: 10.14202/vetworld.2015.572-579. How to cite this article: Singh S, Pathak AK, Sharma RK, Khan M (2015) Effect of tanniferous leaf meal based multi nutrient blocks on feed intake, haematological profile, immune response and body weight changes in Haemonchus contortus infected goats, Veterinary World 8(5):572-579.

\begin{abstract}
Aim: The aim was to assess the effect of multi nutrient block (MNB) supplementation with and without tanniferous leaf meal mixture on feed intake, hematological profile, immune response, and body weight changes of goats that were experimentally infected with Haemonchus contortus.

Materials and Methods: Total 12 adult male goats of similar age and body weight (26.49 \pm 0.87$)$ were allocated in 3 groups in completely randomized design. MNB supplemented in first two groups i.e. in $\mathrm{T}_{1}$ (no infection) and $\mathrm{T}_{2}$ (H. contortus infection@1500 L /goat) group, while, MNB-condensed tannin (CT) supplemented in $\mathrm{T}_{3}$ (H. contortus infection@1500 $\mathrm{L}_{3}$ /goat + CT source). All goats were fed concentrate mixture@100 g/day/goat, ad lib wheat straw and MNB or MNB-CT to meet their requirement for maintenance. Body weights were recorded and blood and fecal samples were collected at 0 day and thereafter at 15 days intervals for a period of 75 days for the assessment of body weight changes, hematological profile and $H$. contortus loads. Both humoral and cell-mediated immune (CMI) response were assessed at the end of feeding trial.

Results: Mean hemoglobin and packed cell volume (PCV) levels were found to be highest $(p<0.001, p<0.05)$ in $T_{1}$ group followed by $T_{3}$ group and lowest values were observed in $T_{2}$ group. However, The PCV values between $T_{1}$ and $T_{3}$ groups were found to be statistically non-significant $(\mathrm{p}<0.05)$. The humoral and CMI response were significantly $(\mathrm{p}<0.036)$ higher in $\mathrm{T}_{3}$ group as compared to $\mathrm{T}_{2}$ group. MNB-CT supplementation significantly $(\mathrm{p}<0.001)$ reduced fecal egg counts in $\mathrm{T}_{3}$ group as compared to $\mathrm{MNB}$ supplemented $\mathrm{T}_{2}$ group.
\end{abstract}

Conclusion: Supplementation of MNB-CT could be used as an alternative sustainable method to control H. contortus and maintained health status and performance of goats in face of parasitic challenge.

Keywords: condensed tannins, goats, Haemonchus contortus, leaf meal mixture, multi-nutrient blocks.

\section{Introduction}

Goat keeping is an attractive enterprise for farmers in many developing countries. Due to its low rearing cost, good economic returns, well adapted in the existing situations and their ability to thrive on locally available alternative feed resources, goat farming under intensive and semi-intensive system for commercial production, emerging favorable market conditions, and easy accessibility to improved goat technologies has been gaining momentum. However, most of the developing countries of the world lie within the limits of the production constraints caused by scarcity of good quality feeds and fodders and gastrointesti nal nematode (GIN) infections are major hindrance to small ruminant production, specifically in the tropical and subtropical regions of the world. Large economic losses can result from reduced body weights, reduced animal production (milk, meat, skin, fiber, and manure), and ultimately reduced animal health and performance in general [1].

Copyright: The authors. This article is an open access article licensed under the terms of the Creative Commons Attributin License (http:// creative commons.org/licenses/by/2.0) which permits unrestricted use, distribution and reproduction in any medium, provided the work is properly cited.
The GINs, predominantly Haemonchus contortus pose a severe threat to sheep and goats, especially those having a poor nutritional status [2-5]. The usual mode of control of these GIN based on the repeated use of anthelmintics, however, evolution of resistance against the most commonly used anthelmintics [6-10] and public concern over drug residues excreted in milk and meat products and their potential risk as environmental contaminants [11] and has a negative impact on their use and alternative approaches for control are needed.

Naturally acquired $H$. contortus infection may cause progressive dramatic fall in packed cell volume (PCV) and hemoglobin $(\mathrm{Hb})$ or may remove a fifth of the circulating erythrocyte volume per day from lambs and on average one tenth of the volume over the course of nonfatal infections lasting a few months [12]. The pathogenic effects result from the inability of the host to compensate for blood loss. If the blood loss is small and the host can adequately compensate for the loss, no measurable illness occurs. However, if the rate of blood loss exceeds the host's hematopoietic capacity a progressive anemia leads to death $[13,14]$. An increasing number of recent studies 
indicate that nutrition could affect GIN infections not only through quantitative variations of different diet components, but also by the presence of some qualitative compounds (Condensed tan nins [CT]) in plants consumed by ruminants. The $\mathrm{CT}$ might interfere directly with the biology of various developmental stages of GINs [4,15-19]. On the other hand, indirectly, CT could also improve the host nutrition by protecting the dietary proteins from ruminal degradations and this could modulate worm biology [20]. Therefore, the key priority for increasing animal productivity is to ensure that the digestion of poor quality crop residue and the proportion between protein and energy in absorbed nutrients are adequate.

Nutritional modulation of infected animals in order to improve the host resistance and/or resilience to GIN infections seems to represent one of the most promising options to reduce the dependence on conventional chemotherapy and to favor the sustainable control of GIN infections [21]. The supplementation strategy is practical and more appropriate in Indian subcontinent where the treatment costs are too high to afford. To achieve this target, the alternative nutritional strategies should be developed and these should include feed supplementation by use of tanniferous leaf meal mixture (LMM) containing multi nutrient blocks (MNB)-CT. The low cost MNB-CT supplements can enhance the animal's ability to utilize the available diet and assist the animal to withstand GIN infection with resultant substantial increase in productivity. The MNB-CT combines these three concepts, ensuring anthelmintic efficacy, balanced supply of nutrients, and improves the utilization of poor quality crop residues in animals [22-25].

The ease of preparation and maintenance make the MNB-CT block technology practicable for non-chemical parasites control strategies, organic food production, and for adoption by landless and marginal farmers. The effectiveness of $\mathrm{CT}$ to control GINs had been widely investigated worldwide. However, the studies pertaining to the effect of CT containing LMM incorporated MNB supplementation in $H$. contortus infected goats are scarce. Therefore, the present study was conducted to investigate the effect of MNB-CT on feed intake, hematological profile, immune response, and body weight changes in goats infected with $H$. contortus infection.

\section{Materials and Methods}

\section{Ethical approval}

Permission of the Institutional Animal Ethics Committee was taken prior to the start of the experimental study.

\section{Tanniferous tree leaves}

Locally available Eugenia jambolana and Psidium guajaba branches were harvested in the month of March-April, 2012 from Faculty premises R. S. Pura, Jammu which is subtropical region of J and $\mathrm{K}$ state. Tree leaves were separated from its branches and air dried in the shed for 15-20 days. Once the tree leaves were dried, they were processed for preparation of leaf meal by grinding in electric grinder. The leaf meals were stored in large perforated nylon bags in a dry place away from direct sunlight for experimental study.

\section{Block manufacturing}

Two types of MNB involved in this study were prepared by cold process. The proportion of ingredients in the MNB and MNB-CT were 35.0, 0.0, 33.0, 7.25, 7.0, 7.75, 4.0, 4.5, 1.5, and 19.5, 16.5, 33.0, 8.5, 6.0, 7.0, 4.0, 4.0, 1.5\%, for mustard oil cake, LMM, molasses, urea, lime stone powder, di-calcium phosphate, mineral mixture, wheat bran, and common salt, respectively. The suitable proportions of wheat bran, mustard oil cake, and urea etc., in MNB were replaced with LMM of E. jambolana and P. guajava dried leaves by making iso-caloric and iso-nitrogenous. The LMM as CT source was only added in MNB-CT blocks at $16.5 \%$ level. In MNB, all processed solidified ingredients were well-mixed and homogenized with liquid mixture composed of water dissolved urea and molasses while in CT containing MNB-CT, LMM of E. jambolana, and P. guajaba in the ratio of 70:30 which was incorporated as $\mathrm{CT}$ source and alternative functional feeds by replacing costlier conventional feed ingredients and then added to solid component which were well mixed and homogenized with above mentioned liquid mixture in a balanced proportion. The properly mixed homogenous semisolid $(2.5 \mathrm{~kg})$ material of both types of blocks was then put in a manually operated multi nutrient brick making machine. The blocks were air dried in the shed for 10-15 days until they are hard enough for easy handling, transport, hanging, and for licking of the experimental animals.

\section{Experimental animals, diet, design, and management}

Twelve local adult male goats $(26.49 \pm 0.87 \mathrm{~kg}$ initial average body weight) were divided randomly into three equal groups in a completely randomized block design. MNB supplemented in first two groups i.e. in $\mathrm{T}_{1}$ (no infection) and $\mathrm{T}_{2}$ (H. contortus infection@1500 L/goat) group, while, MNB-CT supplemented in $\mathrm{T}_{3}$ (H. contortus infection@1500 L / goat + CT source). All goats were fed concentrate mixture (CM)@100 g/day/goat, ad lib wheat straw (WS) and MNB or MNB-CT to meet their requirement for maintenance. Feeding trial was conducted for duration of 75 days excluding 30 days of adaptation on MNB feeding and other management practices before the start of experimental feeding and experimental $H$. contortus. The metabolism trial of 6 days excluding 3 days of adaptation was conducted at the end of feeding trial. Digestible crude protein (DCP) was determined by metabolism trial. The DCP was calculated by subtracting the $\mathrm{CP}$ excreted through feces from CP intake. To determine total digestible nutrient (TDN), the percentage of each nutrient was multiplied by the coefficient of digestibility for that nutrient and 
added together. Therefore, the TDN was the sum of DCP, digestible crude fiber, digestible nitrogen free extract, and digestible ether extract multiplied by 2.25 . The dietary schedule of goats among three groups was depicted in the Table-1. Nutrient requirements for maintenance of all experimental goats were met as per NRC [26].

All goats were kept in a well-ventilated shed having concrete floor throughout the experiment. Hygienic and sanitary conditions were provided in the shed by routinely using disinfectant and detergent. All management conditions viz. deworming, vaccination, etc. were followed as per standard procedures.

\section{Experimental $\boldsymbol{H}$. contortus infection}

Adult female $H$. contortus parasites of caprine origin were collected from the nearest slaughterhouse. The eggs were retrieved from the gravid uterus as per requirement. The infective $3^{\text {rd }}$ stage larvae $\left(\mathrm{L}_{3}\right)$ were produced by petridish method of fecal culture technique. The infective doses of the $3^{\text {rd }}$ stage larvae of $H$. contortus were prepared and administered orally@1500 larvae per goat of $\mathrm{T}_{2}$ and $\mathrm{T}_{3}$ groups.

\section{Laboratory analyses}

The dry matter (DM) content of MNB, MNB-CT, $\mathrm{CM}$, and WS was determined by drying the samples at $100 \pm 5^{\circ} \mathrm{C}$ for $24 \mathrm{~h}$. Kjeldahl nitrogen analyses [27] were performed in triplicate on feeds and $\mathrm{CP}$ calculated as $(\mathrm{N} \times 6.25)$, ether extract content by Soxhlet apparatus and ash content by combustion at $500-550^{\circ} \mathrm{C}$ in muffle furnace. Neutral detergent fiber and acid detergent fiber (ADF) was determined by the Van Soest et al. [28] method. Condensed tannin content was analyzed by the butanol-Hcl method as per Makkar [29]. The Hb concentration in blood was estimated by cyanomet $\mathrm{Hb}$ method. The PCV was estimated by Wintrobe tube method and results were expressed in percent [30].

\section{Body weight changes}

At the start of the experiment, goats were weighed for two consecutive days to get their average initial body weight. The weight of the individual goat was recorded at fortnightly intervals in the morning before feeding and watering for whole experimental period in order to assess the change in body weight.

Table-1: Dietary schedule of goats under different groups.

\begin{tabular}{lccc}
\hline Particulars & $\mathbf{T}_{\mathbf{1}}$ & $\mathbf{T}_{\mathbf{2}}$ & $\mathbf{T}_{\mathbf{3}}$ \\
\hline Goats & 4 & 4 & 4 \\
WS & Ad lib & Ad lib & Ad lib \\
CM $(\mathrm{g} / \mathrm{d})$ & 100 & 100 & 100 \\
MNB & Ad lib & Ad lib & - \\
MNB-CT & - & - & Ad lib
\end{tabular}

*(Maize: 30; wheat bran: 22, mustard oil cake: 45 , mineral mixture: 2 and common salt: 1 ), MNB-CT=Mult nutrient blocks condensed tannins, MNB=Multi nutrient blocks, $\mathrm{CM}=$ Concentrate mixture, WS $=$ Wheat straw

\section{Blood collection}

Blood samples were collected from all experimental goats at the start of the experiment ( 0 day) and thereafter at fortnightly intervals. About $2 \mathrm{~mL}$ of blood was collected aseptically from the jugular vein using 18-gauge needle in a glass vial containing Ethylene di-amine tetra acetate for hematological studies. Immediately after blood collection the tubes were gently rotated between palms in order to mix it with an anticoagulant.

\section{Immune response}

Humoral immune response was assessed through hemagglutination (HA) titer method [31] with slight modifications. Sheep red blood cells (SRBC) were used as antigen. For immunization, $5 \mathrm{~mL}$ of $20 \%$ SRBC suspension was injected subcutaneously in all goats of each group on $55^{\text {th }}$ day of the experiment and same feeding schedule was continued till the end of experiment. A booster dose was injected at $10^{\text {th }}$ day of first injection. On day $21^{\text {st }}$ following SRBC injection, bleeding was done. The antibody production in response to immunization with SRBC was assessed by micro HA test. The reciprocal of highest dilution of serum causing complete HA was taken as HA titer of the serum sample and expressed in $\log _{2}$ values.

The cell-mediated immune (CMI) response was assessed through in vivo cutaneous delayed-type hypersensitivity (DTH) reaction against phytohemagglutinin-p (PHA-p). Toward the end of experimental feeding trial of 75 days, individual goats from each group were used for DTH test. All the goats were injected intra-dermal with $125 \mu 1$ of PHA-p working solution on one side of the neck region. The thickness of the skin was subsequently measured at $12 \mathrm{~h}$ and then $24 \mathrm{~h}$ interval up to $96 \mathrm{~h}$.

\section{Fecal egg counts (FECs)}

Fecal samples of all the experimental goats were collected at the start of the experiment and thereafter at fortnightly intervals till the end of the feeding trial. The fecal samples were collected directly from the rectum early in the morning before feeding and watering. The FECs were estimated by using Stoll's egg counting technique.

\section{Statistical analysis}

All the statistical procedures were done as Snedecor and Cochran [32]. The results obtained were subjected to analysis of variance and treatment means were ranked using Duncan's multiple range test. The periodic alterations in body weight, hematological parameters, and CMI response were analyzed using repeated measures design (General linear model; GLM, Multivariate). Significance was declared at $\mathrm{p}<0.05$ unless otherwise stated.

\section{Results and Discussion}

The chemical composition of CM, WS, MNB, and MNB-CT is given in Table-2. The CT content of MNB-CT was $1.76 \%$. The chemical composition of 
$\mathrm{CM}$ and WS used in the experiment was comparable with the values reported by many workers [4,33-35].

The proportions and ingredients composition used for the preparation of MNB in the present study were contradictory to those used by previous workers $[36,37]$. It might be due to the availability and quality of local feed ingredients. Many workers used cement@10-15\% as a binder for the preparation of MNB [38], while in this study both types of MNB (MNB and MNB-CT) were prepared without cement.

\section{Nutrient intake and plane of nutrition}

Daily nutrient intakes and plane of nutrition by goats among three different groups are presented in the Table-3. Daily intakes (g/d) of CM, MNB, MNB-CT and WS intakes were found to be statistically non-significant $(\mathrm{p}<0.05)$ among $\mathrm{T}_{1}, \mathrm{~T}_{2}$ and $\mathrm{T}_{3}$ groups. Similar trends were also recorded in daily intakes $(\mathrm{g} / \mathrm{d})$ of $\mathrm{DM}$, organic matter $(\mathrm{OM})$, digestible $\mathrm{OM}$, and TDN irrespective of all three groups. However, DCP intake (g/d) was significantly higher in $\mathrm{T}_{1}$ group as compared to $T_{2}$ group, while, $T_{3}$ group has an intermediate

Table-2: Chemical composition of feedstuffs (\% DM except DM).

\begin{tabular}{lcccc}
\hline Attributes & CM & WS & MNB & MNB-CT \\
\hline DM & 90.69 & 92.00 & 86.93 & 87.72 \\
OM & 93.60 & 90.53 & 77.56 & 78.62 \\
CP & 21.62 & 3.19 & 34.69 & 34.47 \\
CF & 8.37 & 38.69 & 1.82 & 2.87 \\
Ether extract & 3.33 & 0.76 & 0.69 & 0.95 \\
Neutral detergent fiber & 0.00 & 82.52 & 13.73 & 13.98 \\
Acid detergent fiber & 0.00 & 53.27 & 4.38 & 6.69 \\
CT & 0.00 & 0.00 & 0.00 & 1.76 \\
\hline
\end{tabular}

$\mathrm{CM}=$ Concentrate mixture, $\mathrm{WS}=$ Wheat straw, $\mathrm{MNB}=$ Multi nutrient block, MNB-CT=Multi nutrient blocks condensed tannins, $\mathrm{DM}=$ Dry matter, $\mathrm{OM}=$ Organic matter, $\mathrm{CP}=$ Crude protein, $\mathrm{CF}=$ Crude fiber, $\mathrm{CT}=$ Condensed tannins position between $\mathrm{T}_{1}$ and $\mathrm{T}_{2}$ groups. Present results are in agreement with the findings of Scharenberg et al. [39], who also reported non-significant difference in total intake of DM, OM, and ADF in H. contortus infected lambs fed on diet with and without tanniferous sainfoin. The CT intake (\% of DMI) from MNB-CT was 0.22 in $\mathrm{T}_{3}$ group. The nutrient intakes in terms of DM, DCP and TDN $(\mathrm{g} / \mathrm{d})$ were remained within the normal range for goats [26] and this clearly indicates both type of supplements (MNB and MNB-CT) along with WS and concentrate for experimental goats were palatable. Present findings suggesting that CT supplementation (as in MNB-CT) at low to moderate level without any adverse effect on DM intake are in consistency with the earlier reports $[35,40]$. Nutrient density (\%) of composite diets in term of DCP and TDN differed significantly $(p<0.05)$ irrespective of groups $\left(\mathrm{T}_{1}, \mathrm{~T}_{2}\right.$, and $\left.\mathrm{T}_{3}\right)$. In the present study, plane of nutrition was not affected adversely with MNB-CT supplementation and inconsistency with the earlier reports [35]. Dutta et al. [41] reported that voluntary feed intake of $H$. contortus infected lambs increased with increasing DCP than those fed lower protein diets. Present study also revealed that DCP and TDN intake was higher in $\mathrm{T}_{3}$ group.

\section{Body weight changes}

The body weight changes of experimental goats for a period of 75 days were presented in Figure-1. Initial body weights $(\mathrm{kg})$ of goats did not differ significantly $(p<0.05)$ irrespective of groups, however, the mean body weight at the end of experiment was significantly $(\mathrm{p}<0.001)$ higher in $\mathrm{T}_{1}$ as compared to $\mathrm{T}_{2}$ group, while $\mathrm{T}_{3}$ groups has an intermediate value between both $\mathrm{T}_{1}$ and $\mathrm{T}_{2}$. As the time period of $H$. contortus infection increased body weight declined significantly $(p<0.001)$ in both infected groups

Table-3: Effect of MNB and MNB-CT on nutrient intake $(\mathrm{g} / \mathrm{d})$ and plane of nutrition by goats during metabolism trial.

\begin{tabular}{|c|c|c|c|c|c|}
\hline \multirow[t]{2}{*}{ Attributes } & \multicolumn{3}{|c|}{ Group* } & \multirow[t]{2}{*}{ SEM } & \multirow[t]{2}{*}{$\mathbf{p}$} \\
\hline & $\mathbf{T}_{1}$ & $\mathbf{T}_{2}$ & $\mathbf{T}_{3}$ & & \\
\hline DM & 634.16 & 599.41 & 627.34 & 12.39 & 0.524 \\
\hline OM & 568.15 & 536.13 & 561.31 & 11.05 & 0.504 \\
\hline $\mathrm{CP}$ & 58.17 & 58.43 & 61.33 & 1.03 & 0.416 \\
\hline Digestible CP & $38.20^{\mathrm{b}}$ & $32.48^{\mathrm{a}}$ & $34.88^{\mathrm{ab}}$ & 0.96 & 0.029 \\
\hline Digestible OM & $345.67^{b}$ & $300.99^{a}$ & $329.36^{\mathrm{ab}}$ & 8.39 & 0.073 \\
\hline Total digestible nutrient & $362.95^{b}$ & $316.04^{a}$ & $345.82^{\mathrm{ab}}$ & 8.81 & 0.073 \\
\hline Concentrate & 90.69 & 90.69 & 90.69 & 0.00 & - \\
\hline Wheat straw & 476.10 & 437.00 & 457.70 & 11.11 & 0.392 \\
\hline MNB & 67.37 & 71.72 & 78.95 & 2.41 & 0.137 \\
\hline \multicolumn{6}{|l|}{ Nutrient density (\%) } \\
\hline Digestible CP & $6.02^{b}$ & $5.42^{\mathrm{a}}$ & $5.57 a$ & 0.10 & 0.018 \\
\hline Total digestible nutrient & $57.29^{b}$ & $52.69^{a}$ & $55.14^{\mathrm{ab}}$ & 0.71 & 0.010 \\
\hline CT \% of DMI & 0.00 & 0.00 & 0.22 & 0.03 & 0.000 \\
\hline \multicolumn{6}{|c|}{ Fecal egg counts (per gram of feces) } \\
\hline $0^{\text {th }}$ day of infection & - & - & - & - & - \\
\hline $21^{\text {st }}$ day of infection & - & $187.50^{\mathrm{b}}$ & $37.50^{\mathrm{a}}$ & 39.81 & 0.000 \\
\hline $75^{\text {th }}$ day of infection & - & $1162.50^{\mathrm{b}}$ & $237.50^{\mathrm{a}}$ & 198.43 & 0.000 \\
\hline
\end{tabular}


$\left(\mathrm{T}_{2}\right.$ and $\left.\mathrm{T}_{3}\right)$ as compared to negative control $\left(\mathrm{T}_{1}\right)$ group. Body weight changes when compared between both infected groups, significantly $(p<0.035)$ reduced body weight was recorded in $T_{2}$ as compared to $T_{3}$ group. Present results conflicted with the findings of previous work ers $[4,42]$ who reported that there was no significant changes in the body weight of sheep infected with $H$. contortus having tanniferous plant (Prosopis cineraria) and tanniferous LMM in their diet in comparison to infected control. A significant amount of protein is redirected for repair of damaged tissues, synthesis and production of immunoglobulin and reducing the amount of protein deposition in the muscles. This leads to reduction of body weight in $\mathrm{T}_{2}$ and $\mathrm{T}_{3}$ as compared to $\mathrm{T}_{1}$ group. However, MNB-CT supplementation gives an indication that binding effect of CT was pronounced at lower level by supplying protein to the lower gut and subsequently it's more efficient use for tissue bear and tears $[35,40]$.

\section{Hematological profile}

$\mathrm{The} \mathrm{Hb}$ and $\mathrm{PCV}$ values of experimental goats among three groups and at different time intervals are depicted in the Figures- 2 and 3 . The $\mathrm{Hb}(\mathrm{g} / \mathrm{dl})$ was found to be highest $(\mathrm{p}<0.001)$ in $\mathrm{T}_{1}$ followed by $\mathrm{T}_{3}$ group and lowest $\mathrm{Hb}$ was observed in $\mathrm{T}_{2}$ group. The PCV values were significantly $(\mathrm{p}<0.001)$ higher in $\mathrm{T}_{1}$ and $\mathrm{T}_{3}$ groups as compared to $\mathrm{T}_{2}$ group, however, the

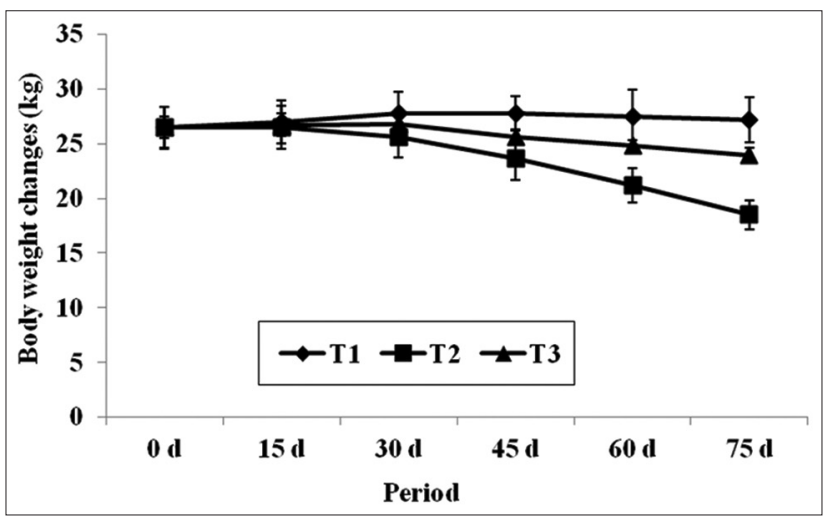

Figure-1: Effect of multi-nutrient block and multi-nutrient block condensed tannin on body weight changes in Haemonchus contortus infected goats.

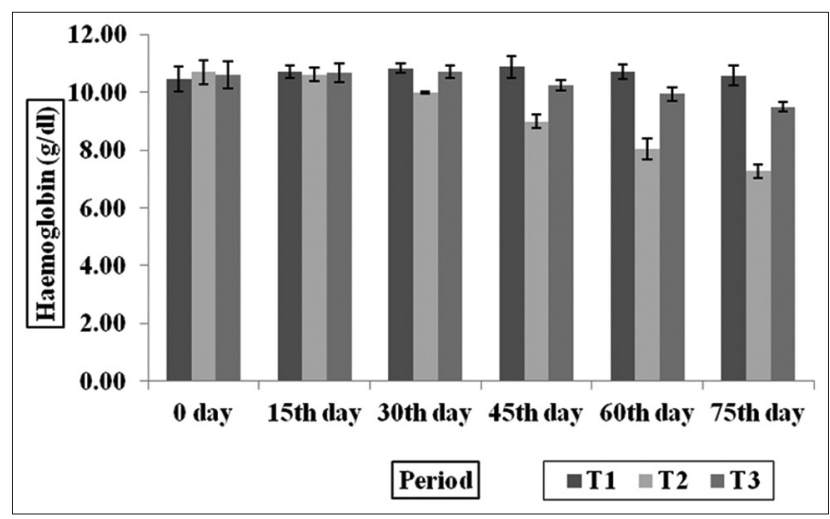

Figure-2: Effect of condensed tannins containing multinutrient blocks on hemoglobin in Haemonchus contortus infected goats.
PCV values between $T_{1}$ and $T_{3}$ groups did not differ significantly. The $\mathrm{Hb}$ and $\mathrm{PCV}$ values were within the normal physiological range suggested for goats [43]. This suggests that the general health of goat's supplemented MNB-CT remained satisfactory throughout the experiment. The observation indicated that low CT level in MNB-CT as an additive and induced no adverse effect on target parameters like $\mathrm{Hb}$ and $\mathrm{PCV}$ in $H$. contortus infected goats. This is in agreement with the finding of Dey et al. [35]; Dubey et al. [44] and Pathak et al. [4] who reported that $0-2 \%$ CT of the diet in lambs and kids during 6 months feeding trial. The $\mathrm{Hb}$ and PCV were maintained in normal physiological range in $T_{3}$ group as compared to $T_{2}$ group, which could be due to the lesser intensity of blood-sucking $H$. contortus parasites and their FECs in $\mathrm{T}_{3}$ group.

\section{Humoral immune response}

Humoral immune response study indicated beneficial effects of $\mathrm{CT}$ supplementation through MNB-CT in infected goats. Mean serum HA titers $(\log 2)$ against SRBC were presented in the Figure-4. There was a significant $(\mathrm{p}<0.05)$ effect on humoral immune response against SRBC in experimental goats of $\mathrm{T}_{3}$ as compared to $\mathrm{T}_{1}$ and $\mathrm{T}_{2}$ groups. Hence, the humoral immune response against SRBC was significantly $(\mathrm{p}<0.05)$ highest in $\mathrm{T}_{3}$ which was offered MNB-CT block and the present finding is supported by Niezen et al. [45] and Min et al. [46]. Similar to

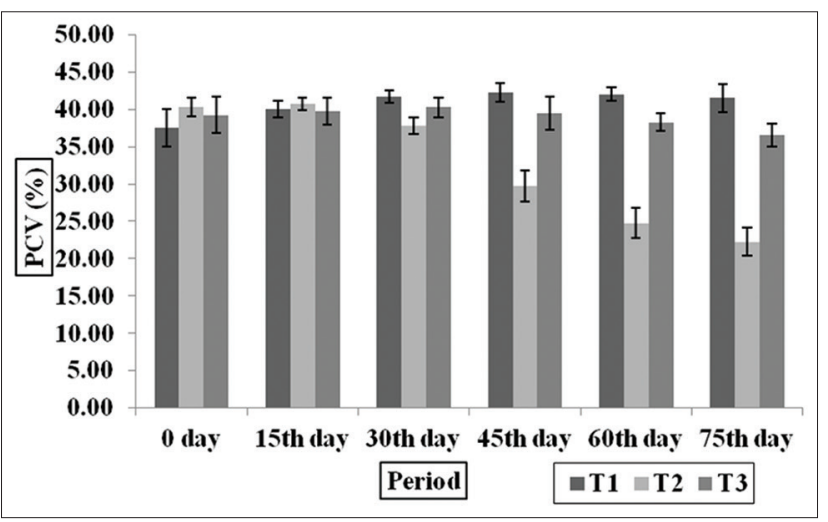

Figure-3: Effect of condensed tannins containing multinutrient blocks on packed cell volume in Haemonchus contortus infected goats.

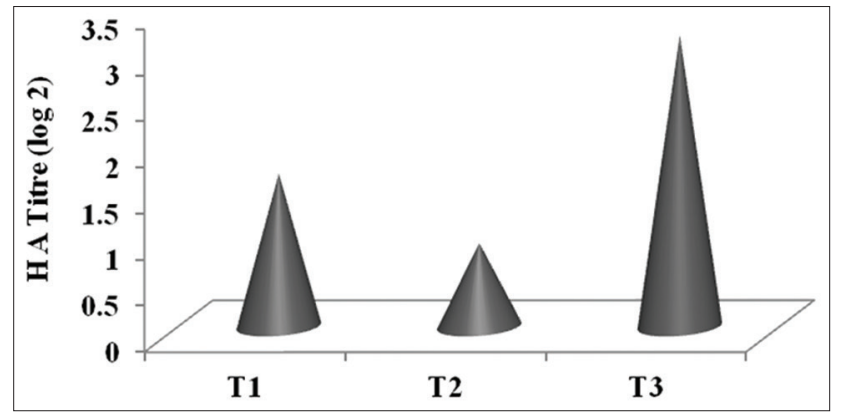

Figure-4: Effect of condensed tannins containing multinutrient blocks supplementation on humoral immune response in goats against sheep red blood cells. 
the present finding Kumar et al. [47] observed that the birds given tannins containing raw red sorghum exhibited higher humoral immune response assessed through HA titer. By making the protein unavailable for digestion and absorption until it reaches the more acidic abomasum, CT also enhance nutrition by providing high-quality protein to the small intestines. This high-quality protein bypass effect has the potential to enhance the immune response and increase resistance to GIN [48]. The positive response of the immune system to protein intake has been shown in metabolism studies with sheep [40], lambs [49], and kids [50]. Bypassing amino acids like arginine, glutamine, and cysteine can enhance immune responses as these amino acids regulate activation of $\mathrm{T}$ and $\mathrm{B}$ lymphocytes, lymphocyte proliferation, and the production of antibodies [51]. The increase in availability of essential amino acids might have contributed to the improved humoral immune response observed in present study.

\section{CMI response}

The CMI response measured as in vivo DTH response to PHA-p in all experimental goats have been presented in the Figure-5. Mean values for skin thickness differed significantly $(\mathrm{p}<0.036)$ among different groups and the maximum $(\mathrm{p}<0.036)$ skin thickness was observed in $\mathrm{T}_{3}$ group as compared to $\mathrm{T}_{2}$ group. However, the mean value of skin thickness $(\mathrm{mm})$ in $T_{1}$ group has an intermediate position between $T_{2}$ and $\mathrm{T}_{3}$ groups. Skin thickness was increased significantly $(\mathrm{p}<0.001)$ from $24 \mathrm{~h}$ post inoculation onward, however, the maximum skin thickness was recorded on $48 \mathrm{~h}$ and $72 \mathrm{~h}$ post-inoculation of PHA-p and then gradually trim down up to $96 \mathrm{~h}$. Therefore, the goats of MNB-CT supplemented group $\left(\mathrm{T}_{3}\right)$ showed significantly higher CMI response to PHA-p as compared to MNB supplemented both groups $\left(\mathrm{T}_{1}\right.$ and $\left.\mathrm{T}_{2}\right)$, which might be attributed to the higher availability of sulfur containing amino acids at abomasal and small intestine level. Lower CT level in feeds given to animals has been reported to increase non-ammonia nitrogen flux to the small intestine, to increase the absorption of essential amino acids. It seems that CT may

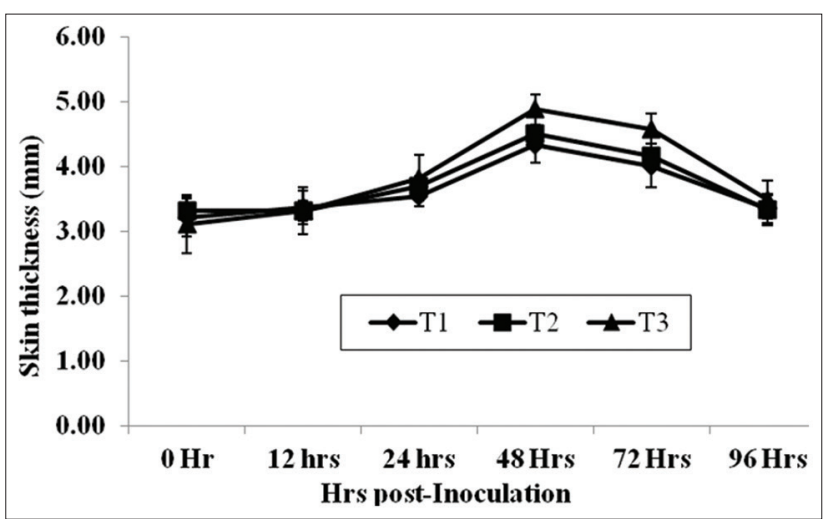

Figure-5: Delayed-type hypersensitivity response to phytohemagglutinin-p in goats on condensed tannins containing multi-nutrient blocks supplementation. have some stimulatory effect to the immune system of the animals $[20,40]$. The significant benefits of MNB-CT supplementation in goats were ascertained as a protein protectant, natural anthelmintic and immunomodulator.

\section{FECS}

At the beginning of the experiment each goat gave zero egg counts, however, after 21 days of experimental $H$. contortus infection in $\mathrm{T}_{2}$ and $\mathrm{T}_{3}$ groups showed passing parasitic eggs in their feces. Though, FECs were zero in goats of $T_{1}$ group throughout the experimental period, so they were not included in the statistical analysis. Mean FECs were significantly $(p<0.001)$ higher in $\mathrm{T}_{2}$ group as compared to $\mathrm{T}_{3}$ group (Table-3). The FECs in $\mathrm{T}_{2}$ group were increased significantly $(\mathrm{p}<0.001)$ throughout the study periods (75 days) relative to their counterparts in $T_{3}$ group. Reduced FECs could be attributed to direct effect of CT on fecundity, killing of adult worms, and indirectly by improving immune function against GIN through enhanced in tissue protein supply [45]. Alternatively, the CT could form a complex with nutrients and inhibit nutrients availability for larval growth or decrease GINs metabolism directly through inhibition of oxidative phosphorylation [52], causing larval death [53]. Pathak et al. $[54,55]$ have reported that CT extracts from various tree leaves can disrupt the life cycle of $H$. contortus by preventing their eggs from hatching and by preventing larval development to the infective stage. The results of present study are in agreement with the previous reports $[4,40]$, who reported that CT supplementation may be used as an alternative parasite management strategy. Both direct and indirect effects of CT against $H$. contortus infection appear to be occurring in the present study.

\section{Conclusion}

It may be concluded that the supplementation of MNB-CT blocks have a noticeable encouraging impact on body weights, hematological profile, and immune response in $H$. contortus infected goats without affecting nutrient intake and utilization. Therefore, this may be the better option as alternative feed supplement/functional feeds and natural dewormer for controlling $H$. contortus infection in goats as socioeconomic, eco-friendly sustainable approach.

\section{Authors' Contributions}

SS was the MVSc Scholar of the division who carried out experimental research work and laboratory analysis of data. AKP was guide of SS, under whose supervision, the thesis was submitted. AKP planned and designed the experiment; formulated condensed tannins enriched multi nutrient blocks, executed statistical analysis of data, drafted and revised the manuscript as per journal format. RKS was head of the division. MK helped in preparation of multi nutrient blocks and assisted in sample analysis in the laboratory. All authors read and approved the final manuscript. 


\section{Acknowledgments}

The authors are highly thankful to Dean, Faculty of Veterinary Science and AH, Director Education and Vice Chancellor of Sher-e-Kashmir University of Agricultural Sciences and Technology of Jammu $(\mathrm{J} \& \mathrm{~K})$, India, for providing necessary facilities and financial support for carrying out the M.V.Sc research work. of first author.

\section{Competing Interests} interests.

The authors declare that they have no competing

\section{References}

1. Mehlhorn, H. (2008) Encyclopedia of Parasitology. Vol. 1. Springer, Dusseldorf, Germany.

2. Pathak, A.K. (2011) Nutritional status and performance of ruminants as influenced by gastrointestinal nematodes An overview. N. E. Vet., XIII(3): 20-26.

3. Pathak, A.K. (2013) Potential of using condensed tannins to control gastrointestinal nematodes and improve small ruminant performance. Int. J. Mol. Vet. Res., 3(8): 36-50.

4. Pathak, A.K., Dutta, N., Banerjee, P.S., Pattanaik, A.K. and Sharma, K. (2013a) Influence of dietary supplementation of condensed tannins through leaf meal mixture on intake, nutrient utilization and performance of Haemonchus contortus infected sheep. Asian Aust. J. Anim. Sci., 26(10): 1446-1458.

5. Pathak, A.K. and Tiwari, S.P. (2013) Effect of high plane of nutrition on the performance of Haemonchus contortus infected kids. Vet. World, 6(1): 22-26.

6. Jackson, F. and Miller, J. (2006) Alternative approaches to control-Quo vadit? Vet. Parasitol., 139(4): 371-384.

7. Miller, J.E. and Horohov, D.W. (2006) Immunological aspects of nematode parasite control in sheep. J. Anim. Sci., 84 Supp 1: E124-E132.

8. Kumsa, B. and Abebe, G. (2009) Multiple anthelmintic resistances on a goat farm in Hawassa (Southern Ethiopia). Trop. Anim. Health Prod., 41(4): 655-662.

9. McKenna, P.B. (2010) Update on the prevalence of anthelmintic resistance in gastrointestinal nematodes of sheep in New Zealand. N. Z. Vet. J., 58(3): 172-173.

10. Torres-Acosta, J.F., Mendoza-de-Gives, P., AguilarCaballero, A.J. and Cuellar-Ordaz, J.A. (2012) Anthelmintic resistance in sheep farms: Update of the situation in the American continent. Vet. Parasitol., 189(1): 89-96.

11. Waller, P.J. (2003) The future of anthelmintics in sustainable parasite control programs for livestock. Helminthology, 40: 97-102.

12. Georgi, J.R. and Georgi, M.E. (1990) Parasitology for Veterinarians. W.B. Saunders Company, Philadelphia, PA.

13. Vatta, A.F., Letty, B.A., Van Der Linde, M.J., Van Wijk, E.F., Hansen, J.W. and Krecek, R.C. (2001) Testing for clinical anaemia caused by Haemonchus spp. in goats farmed under resource-poor conditions in South Africa using an eye colour chart developed for sheep. Vet. Parasitol., 99: 1-14.

14. Waller, D., Beall, A.C. and Loomis, J.M. (2004) Using virtual environments to assess directional knowledge. $J$. Environ. Psychol., 24(1): 105-116.

15. Hoste, H. and Torres-Acosta, J.F. (2011) Non chemical control of helminths in ruminants: Adapting solutions for changing worms in a changing world. Vet. Parasitol., 180(1-2): 144-154.

16. Landau, S., Azaizeh, H., Muklada, H., Glasser, T., Ungar, E.D., Baram, H., Abbas, N. and Markoviccs, A. (2010) Anthelmintic activity of Pistacia lentiscus foliage in two Middle Eastern breeds of goats differing in their propensity to consume tannin-rich browse. Vet. Parasitol., 173: $280-286$.
17. Lem, M.F., Vincent, K.P., Josue, W.P., Jeannette, Y., Gertrude, M.T. and Joseph, T. (2014) In vitro ovicidal and larvicidal activities of stem bark of Terminalia glaucescens (Combretaceae) against Haemonchus contortus. Am. J. Plant Sci., 5: 2859-2868. Available from: http:// www dx doi. org/10.4236/ajps.2014.519301.

18. Max, R.A., Kassuku, A.A., Kimambo, A.E., Mtenga, L.A., Wakelin, D. and Buttery, P.J. (2009) The effects of wattle tannin drenches on gastrointestinal nematodes of tropical sheep and goats during experimental and natural infections. J. Agric. Sci., 147: 211-218.

19. Terrill, T.H., Dykes, G.S., Shaik, S.A., Miller, J.E., Kouakou, B., Kannan, G., Bruke, J.M. and Mosjidis, J.A. (2009). Efficacy of sericea lespedeza hay as a natural dewormer in goats: Dose titration study. Vet. Parasitol., 163: 52-56.

20. Dutta, N., Dubey, M., Banerjee, P.S., Pattanaik, A.K., Sharma, K., Kumar, P. and Narang, A. (2012) Effect of supplementing tanniferous tree leaves mixture on immune response and GI nematodes in kids. Livest. Res. Rural Dev., 24(2).

21. Dey, A. and Paul, S.S. (2014) Gastrointestinal nematodiasis in ruminants: Nutritional consequences and ameliorations. Indian J. Anim. Nutr., 31(2): 101-109.

22. Ibrahim, M., Mubi, A.A. and Mohammed, I.D. (2011) Dusa-based multi-nutrient block in semi-arid environment of Nigeria. J. Agric. Vet. Sci., 3: 1-7.

23. Geleta, T., Negesse, T., Abebe G. and Goetsch, A.L. (2013) Effect of supplementing grazing Arsi-Bale sheep with molasses-urea feed block on weight gain and economic return under farmers' management condition. J. Cell Anim. Biol., 7(10): 125-131.

24. Mubi, A.A., Mohammed, I.D. and Kibon, A. (2012) Effects of multinutrient blocks supplementation on the performance of cattle grazing natural pastures in the wet season of guinea savanna region of Nigeria. World J. Agric. Sci., 8(1): 33-37.

25. Mubi, A.A., Mohammed, I.D. and Kibon, A. (2013) Effects of multinutrient blocks supplementation on the performance of Yankasa sheep fed with basal diet of rice straw in the dry season of guinea savanna region of Nigeria. Arch. Appl. Sci. Res., 5(4): 172-178.

26. NRC. (2007) Nutrient Requirements of Small Ruminants; Sheep, Goats, Servids and New World Camelids. National Academic Press, Washington DC.

27. AOAC. (2000) Official Methods of Analysis. $16^{\text {th }}$ ed. Association of Official Analytical Chemists, Washington, DC.

28. Van Soest, P.J., Robertson, J.B. and Lewis, B.A. (1991) Methods for dietary fiber, neutral detergent fiber and nonstarch polysaccharides in relation to animal nutrition. $J$. Dairy Sci., 74(10): 3583-3597.

29. Makkar, H.P.S. (2000) A Laboratory Manual. Joint FAO/ IAEA Working Document. Quantification of Tannins in Tree Foliage. IAEA, Viena. p1-26.

30. Jain, N.C. (1986) Schalm's Veterinary Haematology. $4^{\text {th }}$ ed. Lea and Febiger, Philadelphia.

31. Hudson, L. and Hay, F.C. (1991) Practical Immunology. $3^{\text {rd }}$ ed. Blackwell Scientific Publications, London.

32. Snedecor, G.W. and Cochran, W.G. (1994) Statistical Methods. $8^{\text {th }}$ ed. East West Press Pvt. Ltd., New Delhi.

33. Sharma, K., Dutta, Dutta, N. and Naulia, U. (2004) An on-farm appraisal of feeding urea treated straw to buffaloes during late pregnancy and lactation in a mixed farming system. Livest. Res. Rural Dev., 16(11): 1-7.

34. Patra, A.K., Sharma, K., Dutta, N. and Pattanaik, A.K. (2006) Effect of partial replacement of dietary protein by a leaf meal mixture on nutrient utilization by goats in pre and late gestation. Small Rumin. Res., 63: 66-74.

35. Dey, A., Dutta, N., Sharma, K. and Pattanaik, A.K. (2008) Effect of dietary inclusion of Ficus infectoria leaves as a protectant of proteins on the performance of lambs. Small Rum. Res., 75: 105-114. 
36. Ben Salem, H., Nefzaoui, A. and Makkar, H.P.S. (2007) Feed supplementation blocks for increased utilization of tanniniferous forages by ruminants. In: Makkar, H.P.S., Sanchez, M. and Speedy, A.W., editors. Feed Supplementation blocks. Urea-molasses multinutrient blocks: Simple and effective feed supplement technology for ruminant agriculture. FAO Animal Production and Health Paper 164. p1-12. Available from: ftp://www.ftp.fao.org/docrep/fao/010/a0242e/ a0242e04.pdf. Last accessed on 09-12-2014.

37. Somasiri, S.C., Premaratne, S., Gunathilake, H.A.J., Abeysoma, H.A. and Satsara, J.H.M. (2010) Development of leaf meal blocks as an animal feed. Trop. Agric. Res., 21(4): 412-420. Available from: http://www.sljol.info/ index.php/TAR/article/view/3317/2691.

38. Aye, P.A. and Adegun, M.K. (2010) Digestibility and growth in West African Dwarf sheep fed gliricidia-based multinutrient block supplements. Agric. Biol. J. North Am., Available from: http://scihub.org/ABJNA/ PDF/2010/6/ ABJNA-1-6-1133-1139.pdf. Last accessed on 05-12-2014.

39. Scharenberg, A., Heckendorn, F., Arrigo, Y., Hertzberg, H., Gutzwiller, A., Hess, H. D., Kreuzer, M. and Dohme, F. (2008). Nitrogen and mineral balance of lambs artificially infected with Haemonchus contortus and fed tanniferous sainfoin (Onobrychis vicifolia). J. Anim. Sci., 86: $1879-1890$.

40. Pathak, A.K., Dutta, N., Banerjee, P.S., Goswami, T.K. and Sharma, K. (2014). Effect of condensed tannins supplementation through leaf meal mixture on voluntary feed intake, immune response and worm burden in Haemonchus contortus infected sheep. J. Parasitol. Dis. DOI 10.1007/ s12639-014-0455-1.

41. Dutta, F.U., Nolan, J.V., Rowe, J.B. and Gray, G.D. (1998) Protein supplementation improves the performance of parasitizd sheep fed a straw-based diet. Int. J. Parasitol., 28: $1269-1278$.

42. Swarnkar, C.P., Singh, D., Khan, F.A. and Vaithiyanathan, S. (2007) Potential role of Tanniferous plant (Prosopis cineraria) in managing Haemonchus contortus infection in sheep. Compendium of Abstracts of XVIII National Congress of Veterinary Parasitology. p158.

43. Kaneko, J.J. (1997) Clinical Biochemistry of Domestic Animals. $5^{\text {th }}$ ed. Academic Press, New York, USA. p885-905.

44. Dubey, M., Dutta, N., Banerjee, P.S., Pattanaik, A.K., Sharma, K. and Singh, M. (2012) Effect of condensed tannins supplementation through a tree leaves mixture on erythrocytic antioxidant status and gastrointestinal nematodes in kids. Anim. Nutr. Feed Tech., 12: 91-102.

45. Niezen, J.H., Charleston, W.A.G., Robertson, H.A., Shelton, D., Waghorn, G.C. and Green, R. (2002) The effect of feeding sulla (Hedysarum coronarium) or lucerne (Medicago sativa) on lambs parasite burdens and immunity to gastrointestinal nematodes. Vet. Parasitol., 105: 229-245.

46. Min, B.R., Hart, S.P., Miller, D., Tomita, G.M., Loetz, E. and Sahlu, T. (2005) The effect of grazing forage containing condensed tannins on gastrointestinal parasite infection and milk composition in Anjora does. Vet. Parasitol., 130: 105-113.

47. Kumar, V., Elangovan, A.V., Mandal, A.B., Tyagi, P.K., Bhanja, S.K. and Dash, B.B. (2007) Effects of feeding raw or reconstituted high tannin red sorghum on nutrient utilization and certain welfare parameters of broiler chickens. Br. Poult. Sci., 48(2): 198-204.

48. Min, B.R., Pomroy, W.E., Hart, S.P. and Sahlu, T. (2004) The effect of short-term consumption of a forage containing condensed tannins on gastrointestinal nematode parasite infections in grazing wether goats. Small Rum. Res., 51: 279-283.

49. Abbott, E.M., Parkin, J.J. and Holmes, P.H. (1988) Influence of dietary protein on the pathophysiology of haemonchosis in lambs given continous infection. Res. Vet. Sci., 45: 41-49.

50. Pathak, A.K. and Tiwari, S.P. (2012) Effect on haematological profile in kids fed different diets with Haemonchus contortus infection. Indian Vet. J., 89(7): 58-59.

51. Li, P., Yu-long, Y., Li, D., Kim, S.W. and Wu, G. (2007) Amino acids and immune function. Br. J. Nutr., 98: 237-252.

52. Scalbert, A. (1991) Antimicrobial properties of tannin. Phytochemistry, 30: 3875-3883.

53. Athanasiadou, S., Kyriazakis, I., Jackson, F. and Coop, R.L. (2001) Direct anthelmintic effects of condensed tannins towards different gastrointestinal nematodes of sheep: In vitro and in vivo studies. Vet. Parasitol., 99: 205-219.

54. Pathak, A.K., Dutta, N., Banerjee, P.S. and Sharma, K. (2013b) Effect of tannin extracts from tropical tree leaves on larvae and adult Haemonchus contortus. Indian Vet. J., 90(1): 32-34

55. Pathak, A.K., Dutta, N., Banerjee, P.S., Sharma, K. and Pattanaik, A.K. (2013c) Efficacy of various condensed tannins extracts from tanniferous tree leaves on egg hatching inhibition of Haemonchus contortus. Vet. Pract., 14(1): 127-129. 